\title{
DETERMINAN PEMBERIAN ASI EKSKLUSIF OLEH IBU YANG MEMILIKI BADUTA
}

\author{
Studi Kasus di Provinsi Kalimantan Barat Tahun 2019 \\ (Determinants of Exclusive Breastfeeding Among Mothers With Under Two Years Old \\ Children, a Case Study in West Kalimantan Province, 2019)
}

\author{
Arif Rahman', Devaki Areta Putrie ${ }^{2}$ \\ Badan Pusat Statistik Kabupaten Sekadau ${ }^{1,2}$ \\ Jalan Merdeka Timur Km. 09, Komp. Perkantoran Pemda Sekadau \\ E-mail: rahman.arif@bps.go.id
}

\begin{abstract}
ABSTRAK
Dalam menentukan derajat kesehatan, terdapat beberapa indikator yang dapat digunakan salah satunya Angka Kematian Bayi (AKB). Pada tahun 2017, AKB di Indonesia masih ada sekitar 24 kasus dari 1000 kelahiran hidup. Padahal, Sustainable Development Goals (SDGs) menargetkan pada tahun 2030 AKB pada seluruh negara di dunia turun menjadi 12 kasus dari 1000 kelahiran hidup. Salah satu upaya untuk menurunkan AKB adalah dengan memberikan ASI eksklusif. Selama periode 2015-2017, persentase bayi yang mendapat ASI eksklusif di Kalimantan Barat selalu berada dibawah angka nasional dan bahkan menjadi yang terendah di Pulau Kalimantan. Penelitian ini bertujuan untuk mendeskripsikan karakteristik ibu yang memiliki baduta untuk memberikan ASI eksklusif, mengetahui variabel-variabel yang berpengaruh serta menganalisis kecenderungannya terhadap pemberian ASI eksklusif oleh ibu yang memiliki baduta di Provinsi Kalimantan Barat tahun 2019. Adapun teknik analisis yang digunakan yaitu regresi logistik biner. Hasil dari penelitian ini adalah secara umum, pemberian ASI eksklusif di Provinsi Kalimantan Barat banyak ditemukan pada ibu yang berusia 25-34 tahun, berpendidikan sekolah menengah ke atas, tinggal di perdesaan, berstatus tidak bekerja, bukan rumah tangga miskin, dan penolong saat melahirkan adalah tenaga medis. Selanjutnya, variabel-variabel yang berpengaruh signifikan terhadap pemberian ASI eksklusif oleh ibu yang memiliki baduta di Provinsi Kalimantan Barat tahun 2019 yaitu tingkat pendidikan, status bekerja, dan status kemiskinan rumah tangga.
\end{abstract}

Kata kunci: Baduta, ASI eksklusif, regresi logistik biner

\section{ABSTRACT}

In determining the degree of health, there are several indicators that can be used, one of which is the Infant Mortality Rate (IMR). In 2017, there were still around 24 cases of IMR out of 1000 live births. In fact, the Sustainable Development Goals (SDGs) are targeting that by 2030 the IMR in all countries in the world will drop to 12 cases out of 1000 live births. One of the efforts to reduce IMR is by giving exclusive breastfeeding. During the 2015-2017 period, the percentage of babies who were exclusively breastfed in West Kalimantan was always below the national figure and even the lowest in Kalimantan. This study aims to describe the characteristics of mothers who have underwent exclusive breastfeeding, determine the influencing variables and analyze their tendency towards exclusive breastfeeding by mothers who have under two years old children in West Kalimantan Province in 2019. The analysis technique used is binary logistic regression. The results of this study is that in general, exclusive breastfeeding in West Kalimantan Province was found in mothers aged 25-34 years, with high school education, living in rural areas, not working, not in poor households, and assisting during childbirth. medical personnel. Furthermore, the variables that have a significant effect on exclusive breastfeeding by mothers who have baduta in West Kalimantan Province in 2019 are education level, work status, and household poverty status.

Keywords: under two years old children, exclusive breastfeeding, binary logistic regression

\section{PENDAHULUAN}

Dalam menentukan derajat kesehatan, terdapat beberapa indikator yang dapat digunakan, antara lain angka harapan hidup pada saat lahir, angka kesakitan bayi, status gizi, dan angka kematian bayi. Menurut World Health Organization (WHO), Angka Kematian Bayi (AKB) menjadi salah satu indikator utama dalam menentukan derajat kesehatan anak karena merupakan 
cerminan dari status kesehatan anak saat ini (WHO, 2002). Pada tahun 2017, AKB di Indonesia masih ada sekitar 24 kasus dari 1000 kelahiran hidup. Padahal, Sustainable Development Goals (SDGs) menargetkan pada tahun 2030 AKB pada seluruh negara di dunia turun menjadi 12 kasus dari 1000 kelahiran hidup.

Salah satu upaya untuk menurunkan AKB adalah dengan memberikan ASI eksklusif. Menurut WHO, menyusui eksklusif didefinisikan sebagai tidak memberikan makanan atau minuman lain (bahkan air) kecuali ASI selama 6 bulan pertama kehidupan, tetapi memungkinkan bayi untuk menerima oralit, tetes dan sirup (vitamin, mineral dan obat-obatan). ASI sangat penting untuk mendukung perkembangan bayi dan untuk mengurangi resiko kematian bayi karena mengandung kolostrum yang kaya akan antibodi untuk daya tahan tubuh dan pembunuh kuman dalam jumlah tinggi. Bayi yang tidak mendapatkan ASI secara eksklusif selama 6 bulan, lebih rentan mengalami masalah kesehatan di masa depan (Kramer dkk, 2004).

Di Indonesia, target Kementrian Kesehatan (Kemenkes) untuk cakupan ASI eksklusif pada tahun 2014 yaitu sebesar 80 persen. Namun, berdasarkan hasil Susenas Maret tahun 2017, cakupan ASI eksklusif di Indonesia baru mencapai 55,96 persen. Sementara itu, selama periode 2015-2017 persentase bayi yang mendapat ASI eksklusif di Kalimantan Barat selalu berada dibawah angka nasional dan bahkan menjadi yang terendah di Pulau Kalimantan.

Salah satu faktor yang memengaruhi pemberian ASI eksklusif yaitu status ekonomi rumah tangga. Ibu yang berstatus sosial ekonomi rendah memiliki peluang lebih besar untuk memberikan ASI eksklusif dibandingkan dengan ibu yang berstatus sosial ekonomi tinggi (Purnamawati, 2003). Selain itu, karakteristik sang ibu juga ikut berperan penting dalam pemberian ASI eksklusif, misalnya tingkat pendidikan, status pekerjaan, dan umur (Paramashanti dkk, 2016).

Saat ini, BPS juga mengumpulkan data terkait pemberian ASI eksklusif yang tercakup dalam Survei Sosial Ekonomi Nasional (Susenas) blok keterangan imunisasi, ASI, dan MP-ASI. Dalam survei tersebut, pemberian ASI eksklusif ditanyakan pada rumah tangga yang memiliki anak berusia di bawah dua tahun (baduta). Dengan demikian, penelitian terkait pemberian ASI eksklusif hanya bisa dilakukan pada ibu yang memiliki baduta.

Berdasarkan latar belakang permasalahan dan ketersediaan data yang telah diuraikan sebelumnya, maka penelitian terkait pemberian ASI eksklusif oleh ibu yang memiliki baduta penting untuk dilakukan. Adapun tujuan utama dari penelitian ini adalah untuk mendeskripsikan gambaran umum karakteristik ibu yang memiliki baduta untuk memberikan ASI eksklusif di Provinsi Kalimantan Barat tahun 2019. Tujuan selanjutnya yaitu untuk mengetahui variabelvariabel yang berpengaruh serta menganalisis kecenderungannya terhadap pemberian ASI eksklusif di Provinsi Kalimantan Barat tahun 2019.

\section{METODE}

Penelitian ini menggunakan data primer, yaitu data mikro Survei Sosial Ekonomi Nasional (Susenas) KOR Maret 2019. Data tersebut dikumpulkan oleh Badan Pusat Statistik (BPS) melalui wawancara langsung dengan kuesioner "VSEN19.MKP". Cakupan wilayah dan waktu pada penelitian ini adalah di Provinsi Kalimantan Barat pada bulan Maret tahun 2019.

Unit analisis dalam penelitian ini yaitu ibu usia 15-49 tahun yang memiliki baduta. Variabel dependen yang digunakan adalah status pemberian ASI oleh ibu yang memiliki baduta yang dibagi ke dalam dua kategori yaitu eksklusif dan tidak eksklusif. Adapun variabel independen yang digunakan dalam penelitian ini terdiri dari umur, tingkat pendidikan, daerah tempat tinggal, status bekerja, status kemiskinan rumah tangga, dan penolong saat melahirkan.

Tabel 1. Variabel Penelitian

\begin{tabular}{llc}
\hline \multicolumn{1}{c}{ Variabel } & \multicolumn{1}{c}{ Kategori } & Dummy \\
\hline Variabel Dependen & & \\
Status pemberian ASI & $\begin{array}{l}\text { Tidak eksklusif } \\
\text { Eksklusif* }\end{array}$ & 0 \\
Variabel Independen & & 1 \\
Umur & 15-24 tahun & 0 \\
& 25-34 tahun & 0 \\
& 35-49 tahun & 1 \\
\hline
\end{tabular}




\begin{tabular}{lll}
\hline Tingkat pendidikan & SD ke bawah & 0 \\
\multirow{2}{*}{ Daerah tempat tinggal } & Menengah ke atas & 1 \\
& Perdesaan & 0 \\
Status bekerja & Perkotaan & 1 \\
\multirow{3}{*}{ Status kemiskinan } & Tidak bekerja & 0 \\
\multirow{2}{*}{ Penolong saat melahirkan } & Bekerja & 1 \\
& Miskin & 0 \\
& Tidak miskin & 1 \\
& Bukan tenaga medis & 0 \\
& Tenaga medis & 1 \\
\hline
\end{tabular}

Metode analisis yang digunakan terdiri dari analisis deskriptif dan inferensia. Dalam penelitian ini, analisis deskriptif digunakan untuk memberikan gambaran umum tentang karakteristik ibu yang memiliki baduta di Kabupaten Sekadau yang disajikan dalam bentuk tabel.

Sementara itu, analisis inferensia digunakan untuk menentukan pengaruh variabel independen terhadap variabel dependen (status pemberian ASI), serta menentukan kecenderungan variabel independen terhadap status pemberian ASI oleh ibu yang memiliki baduta. Teknik analisis yang digunakan adalah regresi logistik biner dengan tingkat signifikansi 5 persen.

Dalam regresi logistik biner, variabel dependen terdiri dari dua kategori yaitu "sukses" dan "gagal" yang diberi kode 1 dan 0 . Untuk setiap variabel respon $(Y), \pi(x)$ menunjukkan peluang kejadian "sukses" dengan nilai $x$ tertentu. Menurut Hosmer dan Lemeshow (2000), model regresi logistik biner secara umum didefinisikan sebagai:

$$
\pi(x)=\frac{\exp \left(\beta_{0}+\beta_{1} x_{1}+\cdots+\beta_{p} \beta_{p}\right)}{1+\exp \left(\beta_{0}+\beta_{1} x_{1}+\cdots+\beta_{p} \beta_{p}\right)}
$$

Model tersebut bersifat non-linier, sehingga untuk mengubah model regresi logistik menjadi linier digunakan transformasi logit sebagai berikut:

$$
\pi(x)=\ln \left[\frac{\pi(x)}{1+\pi(x)}\right]=\beta_{0}+\beta_{1} x_{1}+\cdots+\beta_{p} \beta_{p}
$$

Tahapan analisis regresi logistik biner dalam penelitian ini adalah sebagai berikut:

1. Pendugaan koefisien parameter dengan metode Maximum Likelihood Estimation (MLE).

2. Pengujian signifikansi parameter secara simultan (likelihood ratio test) dan secara parsial (Wald test). Hipotesis nol dari uji simultan adalah tidak ada variabel independen yang signifikan terhadap variabel dependen. Kemudian, hipotesis nol untuk uji parsial adalah tidak ada pengaruh variabel independen ke-j terhadap variabel dependen. Hasil yang diharapkan adalah tolak $H_{0}$ untuk kedua uji tersebut yang ditandai dengan nilai $p$-value lebih kecil dari tingkat signifikansi (5 persen).

3. Pengujian kesesuaian model dengan Hosmer \& Lemeshow test. Hipotesis nol dari uji ini adalah model fit (sesuai). Hasil yang diharapkan adalah gagal tolak $H_{0}$ yang ditunjukkan dengan nilai $p$-value lebih besar dari tingkat signifikansi (5 persen).

4. Interpretasi dari rasio kecenderungan (odds ratio).

\section{HASIL DAN PEMBAHASAN}

Dari Table 2, dapat diketahui bahwa persentase ibu yang memberikan ASI secara eksklusif di Kalimantan Barat sebesar 43,07 persen, sedangkan ibu yang tidak memberikan ASI secara eksklusif sebesar 56,93 persen. Hal ini menandakan bahwa pada tahun 2019, ibu yang memiliki baduta di Provinsi Kalimantan Barat masih banyak yang tidak memberikan ASI secara eksklusif atau dengan kata lain terdapat sekitar 1 dari 2 orang ibu di Provinsi Kalimantan Barat belum memberikan ASI secara eksklusif. Angka tersebut mengindikasikan bahwa tingkat kesadaran ibu untuk memberikan ASI secara eksklusif di Kalimantan Barat relatif masih rendah.

Tabel 2. Karakteristik Ibu yang Memiliki Baduta di Provinsi Kalimantan Barat tahun 2019

\begin{tabular}{ccc}
\hline \multicolumn{2}{c}{ Karakteristik Ibu } & Persentase \\
\hline Pemberian ASI & Bukan ASI eksklusif & 56,93 \\
\hline
\end{tabular}




\begin{tabular}{lll}
\hline & ASI eksklusif* & 43,07 \\
Umur & 15-24 tahun & 32,24 \\
& 25-34 tahun & 48,84 \\
& $35-49$ tahun & 18,92 \\
Tingkat & SD ke bawah & 39,81 \\
pendidikan & Menengah ke atas & 60,19 \\
Daerah tempat & Perdesaan & 68,21 \\
tinggal & Perkotaan & 31,79 \\
& & 67,96 \\
Status bekerja & Tidak bekerja & 32,04 \\
& Bekerja & 12,45 \\
Status & Miskin & 87,55 \\
kemiskinan & Tidak miskin & 13,72 \\
Penolong saat & Bukan tenaga medis & 86,28 \\
\hline
\end{tabular}

Berdasarkan variabel independen yang digunakan, karakteristik ibu yang memiliki baduta di Provinsi Kalimantan Barat tahun 2019 didominasi oleh kelompok umur 25-34 tahun (48,84 persen), berpendidikan menengah ke atas $(60,19$ persen), bertempat tinggal di daerah perdesaan (68,21 persen), berstatus tidak bekerja (67,96 persen), bukan dari rumah tangga miskin (87,55 persen), dan penolong saat melahirkan dibantu oleh tenaga medis $(86,28)$.

Tabel 3. Karakteristik Ibu yang Memiliki Baduta berdasarkan Status Pemberian ASI dan Variabel Independen di Provinsi Kalimantan Barat tahun 2019

\begin{tabular}{llc}
\hline \multicolumn{1}{c}{ Karakteristik Ibu } & $\begin{array}{c}\text { Pemberian } \\
\text { ASI Eksklusif }\end{array}$ \\
\hline Umur & 15-24 tahun & 29,28 \\
& 25-34 tahun & 50,80 \\
Tingkat & SD ke bawah & 19,92 \\
pendidikan & Menengah ke atas & 34,47 \\
& & 65,53 \\
Daerah tempat & Perdesaan & 69,82 \\
tinggal & Perkotaan & 30,18 \\
Status bekerja & Tidak bekerja & 59,33 \\
& Bekerja & 40,67 \\
Status & Miskin & 12,34 \\
kemiskinan & Tidak miskin & 87,66 \\
Penolong saat & Bukan tenaga medis & 13,98 \\
melahirkan & Tenaga medis & 86,02 \\
\hline
\end{tabular}

Berdasarkan pada Tabel 3, karakteristik ibu yang memberikan ASI secara eksklusif di Provinsi Kalimantan Barat tahun 2019 didominasi oleh kelompok umur 25-34 tahun (50,80 persen), berpendidikan menengah ke atas (65,53 persen), bertempat tinggal di daerah perdesaan $(69,82$ persen), berstatus tidak bekerja (59,33 persen), bukan dari rumah tangga miskin (87,66 persen), dan penolong saat melahirkan dibantu oleh tenaga medis $(86,02)$.

Berdasarkan hasil pengujian signifikansi parameter secara simultan, diperoleh nilai statistik uji $\mathrm{G}(1366,515)$ lebih besar dari nilai kritis pada chi square tabel $(29,744)$ dan $p$-value $<0,05$ yang berarti tolak $\mathrm{H}_{0}$. Dengan demikian, dapat diambil kesimpulan bahwa pada tingkat signifikansi lima 
persen, terdapat cukup bukti untuk mengatakan bahwa minimal ada satu variabel independen yang berpengaruh signifikan terhadap variabel dependen.

Berikut adalah rangkuman hasil pengujian parameter secara parsial untuk seluruh variabel independen yang digunakan dalam penelitian ini:

Tabel 3. Tabel Rangkuman Hasil Pengolahan Uji Parsial Regresi Logistik Biner

\begin{tabular}{lrrrr}
\hline \multicolumn{1}{c}{ Variabel } & \multicolumn{1}{c}{ B } & \multicolumn{1}{c}{ Wald } & p-value & \multicolumn{1}{c}{ Exp(B) } \\
\hline Umur (15-24) & $-0,286$ & 2,372 & 0,124 & 0,751 \\
Umur (25-34) & $-0,181$ & 1,234 & 0.267 & 0,835 \\
Tingkat pendidikan (SD ke bawah) & $-0,337$ & 5,784 & 0,016 & 0,714 \\
Daerah tempat tinggal (Perdesaan) & 0,208 & 1,978 & 0,160 & 1,231 \\
Status bekerja (Tidak bekerja) & $-0,534$ & 14,814 & 0,000 & 0,586 \\
Status kemiskinan (Miskin) & 0,408 & 4,449 & 0,035 & 1,503 \\
Penolong saat melahirkan (Bukan tenaga medis) & 0,019 & 0,010 & 0,922 & 1,019 \\
Konstanta & 0,202 & 1,145 & 0,285 & 1,223 \\
\hline
\end{tabular}

Berdasarkan tabel rangkuman di atas, maka keputusan yang diambil adalah tolak $\mathrm{H}_{0}$ untuk variabel tingkat pendidikan, status bekerja, dan status kemiskinan. Keputusan tersebut diambil karena nilai $p$-value untuk ketiga variabel tersebut lebih kecil dari 0,05 . Dengan demikian, dapat diambil kesimpulan bahwa dengan tingkat signifikansi lima persen, terdapat cukup bukti untuk mengatakan bahwa variabel tingkat pendidikan, status bekerja, dan status kemiskinan berpengaruh signifikan terhadap pemberian ASI secara eksklusif oleh ibu yang memiliki baduta.

Dari hasil uji parsial tersebut, maka dapat dituliskan persamaan regresi logistik biner yang terbentuk adalah sebagai berikut:

$$
\begin{aligned}
\pi(x)=\ln \left[\frac{\pi(x)}{1-\pi(x)}\right]= & 0,202-0,286 \operatorname{Umur}(1)-0,181 \operatorname{Umur}(2)-0,337 \text { Pendidikan }(1)^{*}+ \\
& \text { 0,208Daerah }(1)-0,534\left(\text { StatusBekerja }(1)^{*}+\operatorname{StatusKemiskinan}(1)^{*}+\right. \\
& 0,019 \text { Penolong } \ldots \ldots \ldots \ldots \ldots \ldots \ldots \ldots \ldots \ldots \ldots \ldots \ldots \ldots \ldots \ldots \ldots \ldots \ldots \ldots \ldots \ldots \ldots \ldots \ldots \ldots \ldots \ldots \ldots \ldots \ldots \ldots \ldots \ldots \ldots \ldots \ldots \ldots \ldots \ldots \ldots \ldots \ldots \ldots \ldots \ldots \ldots \ldots \ldots \ldots \ldots \ldots
\end{aligned}
$$

keterangan: $*=$ signifikan pada tingkat signifikansi 5 persen

Selanjutnya dilakukan pengujian kesesuaian model menggunakan Hosmer \& Lemeshow test. Berdasarkan hasil pengujian kesesuaian model menggunakan SPSS diperoleh nilai $p$-value sebesar 0,483 yang berarti gagal tolak $H_{0}$. Dengan demikian, dapat disimpulkan model yang diperoleh sudah fit (sesuai).

Berikut adalah interpretasi rasio kecenderungan (odds ratio) untuk variabel independen yang signifikan memengaruhi pemberian ASI eksklusif oleh ibu yang memiliki baduta di Provinsi Kalimantan Barat tahun 2019:

\section{Pendidikan}

Pendidikan terakhir yang ditamatkan oleh ibu berpengaruh secara signifikan terhadap status pemberian ASI di Kalimantan Barat. Ibu dengan pendidikan tertinggi SMP/sederajat ke atas memiliki kecenderungan untuk memberikan ASI secara eksklusif sebesar 1,400 kali dibandingkan ibu yang berpendidikan SD/sederajat ke bawah ketika semua variabel lain konstan. Hal ini karena ibu yang berpendidikan lebih tinggi cenderung memiliki pengetahuan yang lebih baik mengenai pentingnya nutrisi untuk bayi mereka, terutama pemberian ASI secara eksklusif.

\section{Status Bekerja}

Variabel independen selanjutnya yang signifikan mempengaruhi status pemberian ASI eksklusif oleh ibu yang memiliki baduta di Kalimantan Barat tahun 2019 adalah status bekerja. Ibu yang berstatus tidak bekerja akan memiliki kecenderungan untuk memberikan ASI secara eksklusif sebesar 1,706 kali lebih besar dibandingkan ibu dengan status bekerja. Hal ini karena ibu yang bekerja akan memiliki waktu yang lebih terbatas untuk memberikan ASI kepada anaknya, bahkan tidak jarang ditemukan seorang ibu lebih memilih untuk memberikan susu formula untuk bayi mereka sebagai susu pendamping ketika mereka sedang bekerja. 


\section{Status Kemiskinan}

Status kemiskinan juga berpengaruh signifikan terhadap pemberian ASI eksklusif oleh ibu yang memiliki baduta di Provinsi Kalimantan Barat tahun 2019. Ibu yang berasal dari rumah tangga miskin akan memiliki kecenderungan untuk memberikan ASI secara eksklusif sebesar 1,503 kali lebih besar dibandingkan ibu yang bukan dari rumah tangga tidak miskin. Fenomena ini bisa saja terjadi karena ibu yang berasal dari rumah tangga miskin akan memiliki keterbatasan untuk memberikan makanan lain akibat tidak adanya biaya untuk membelikan bayi mereka makanan tambahan. Berbeda halnya dengan ibu yang berasal dari rumah tangga tidak miskin, mereka memiliki kelebihan secara finansial sehingga bayi mereka akan mendapat makanan tambahan lain selain ASI.

\section{KESIMPULAN}

Berdasarkan hasil penelitian yang telah diuraikan diatas, maka diambil beberapa kesimpuan yaitu pertama, persentase ibu yang memberikan ASI secara eksklusif di Kalimantan Barat sebesar 43,07 persen. Kedua, karakteristik ibu yang memiliki baduta di Provinsi Kalimantan Barat tahun 2019 didominasi oleh kelompok umur 25-34 tahun, berpendidikan menengah ke atas, bertempat tinggal di daerah perdesaan, berstatus tidak bekerja, bukan dari rumah tangga miskin, dan penolong saat melahirkan dibantu oleh tenaga medis. Ketiga, karakteristik ibu yang memberikan ASI secara eksklusif di Provinsi Kalimantan Barat tahun 2019 didominasi oleh kelompok umur 2534 tahun, berpendidikan menengah ke atas, bertempat tinggal di daerah perdesaan, berstatus tidak bekerja, bukan dari rumah tangga miskin, dan penolong saat melahirkan dibantu oleh tenaga medis. Keempat, variabel tingkat pendidikan, status bekerja, dan status kemiskinan berpengaruh signifikan terhadap pemberian ASI secara eksklusif oleh ibu yang memiliki baduta di Provinsi Kalimantan Barat tahun 2019.

\section{DAFTAR PUSTAKA}

Agresti, A. (2002). Categorical Data Analysis (2nd ed). New York: John Wiley \& Sons.

Alemayehu, T., Jemal H., Dereje H. (2009). Determinants of Exclusive Breastfeeding Practices in Ethiopia. Ethiop.J.Health Dev. 23(1): 12-18.

Asra, A., Puguh B.I., Agus P. (2014). Metode Penelitian Survei. Bogor: In Media.

Batal, M., Chogik, B., Ahmad, A., Rima, A. (2005). Breastfeeding and Feeding Practices of Infants in A Developing Country: A National Survey in Lebanon. Public Health Nutrition. 9(3): 313-319.

Fikawati, S. \& Ahmad, S. (2003). Penyebab Keberhasilan dan Kegagalan Praktik Pemberian ASI Eksklusif. Jurnal Kesehatan Masyarakat Nasional. 4(3): 120-131.

Gunarsa. (2000). Psikologi Praktis: Anak Remaja dan Keluarga. Jakarta: PT. BPK Gunung Mulia.

Hamidi. (2004). Metode Penelitian Kualitatif: Aplikasi Praktis Pembuatan Proposal dan Laporan Penelitian. Malang: UMM Press. 14-16.

Hidayat, A.A. (2008). Pengantar IImu Kesehatan Anak untuk Pendidikan Kebidanan. Jakarta: Salemba Medika.

Hosmer, D. W. \& Lemeshow, S. (2000). Applied Logistic Regression. John Wiley \& Sons.

Jain, A.K. \& John, B. (1981). Breastfeeding: Patterns, Correlates, and Fertility Effects. Studies in Family Planning, 12(3): 79-99.

Joesoef, M.R., Utomo, B., Lewis, G.L. (1988). Breastfeeding Practices in Metropolitan Indonesia: Policy Concideration. Journal of Tropical Pediatrics. 34: 270-274.

Kramer, Michael S., Ritsuko K. (2004). The Optimal Duration of Exclusive Breastfeeding: Protecting Infants Trough Human Milk. Boston: Springer. 63-77.

Kumala, A. (2017). Factors Associated with Exclusive Breastfeeding at Primary Health Care in Indonesia. Pediatr Ther. 7(4).

Lestari, D., Reni, Z., Larasati, T.A. (2013). Hubungan Tingkat Pengetahuan Ibu tentang Air Susu Ibu dan Pekerjaan Ibu dengan Pemberian ASI Eksklusuif di Kelurahan Fajar Bulan. Medical Journal of Lampung University. 2(4).

Mitra. (2010). Faktor-Faktor yang Berhubungan dengan Kelangsungan Pemberian ASI Eksklusif di Indonesia. Jurnal Kesehatan Masyarakat. 4(2): 82-87.

Motee, A., Deerajen, R., Prity, P. G., Rajesh, J. (2013). An Assesment of The Breastfeeding Practices and Infant Feeding Pattern among Mothers in Mauritius. Journal of Nutritions and Metabolism. 1-8.

Nazir, M. (1988). Metode Penelitian. Jakarta: Ghalia Indonesia. 
Nurmiati \& Besral. (2008). Durasi Pemberian ASI terhadap Ketahanan Hidup Bayi di Indonesia. Makara Kesehatan. 12(2): 47-52.

Paramashanti, B.A., Hamam, H., I Made, A.G. (2016). Timely Initiation of Breastfeeding is Associated with The Practice of Exclusive Breastfeeding in Indonesia. Asia Pac J Clin Nutr. 25(1): 52-56.

Prasetyono. (2009). Buku Pintar ASI Eksk/usif. Yogyakarta: Diva Press.

Purnamawati, S. (2003). Faktor-Faktor yang Berpengaruh dengan Pola Pemberian ASI pada Bayi Usia Empat Bulan (Analisis Data Susenas 2001). Media Litbang Kesehatan. 13(3): 29-37.

Purwanti, H.S. (2004). Konsep Penerapan ASI Eksklusif Buku Saku Bidan. Jakarta: EGC.

Reddy, S. \& Teshome, A. (2016). Determinants of Exclusive Breastfeeding Practice among Mothers of Children Under Two Years Old in Dilla Zuria District, Godeo Zone, Snnpr, Ethiopia, 2014. Journal of Pregnancy and Child Health. 3(1): 1-6.

Ramachandran, K.M., \& Chris, P.T. (2008). Mathematical Statistics with Application. USA: Elsevier.

Ryan, A.S., \& Gilbert A.M. (1989). Breastfeeding and The Working Mother: A Profile. Pediatrics. 83(4): 524531. 